\title{
The Great Game that Never Ends: China emerges as leading player in Kazakhstan
}

\author{
Anurag Tripathi*
}

\section{Abstract}

Kazakhstan occupies a unique geopolitical position in Eurasia. Kazakhstan has gradually emerged as a regional power as a result of its economic progress and 'multivector' foreign policy. China's policy in Kazakhstan is linked to its larger strategic and geo-political interests following the disintegration of the former USSR. China's economic policy is also largely based on its energy security needs and search for a market for its finished goods. Simultaneously, there is also a fear among Chinese policy makers with regard to the 'opening up 'of its north western frontier towards the Muslim Republics of Central Asia as it involves the risk of Islamic fundamentalism and cross-border ethnic separatism that may pose grave threat to China's national security. China has achieved a significant advantage over any potential competitor and has created an important infrastructure base in Kazakhstan. Kazakhstan's foreign cooperation with Russia or the West will no longer change this trend of increased interaction with China.

Keywords: Geopolitics, Shanghai Cooperation Organization, Shanghai Five, Silk Route, Historic Border Accord, Strategic Balance

* Christ University, Bengaluru, India; anurag.tripathi@christuniversity.in 


\section{Introduction}

After the collapse of the former Soviet Union, the Central Asian Republic of Kazakhstan emerged as an independent and sovereign country. Kazakhstan was born as an independent republic country from the disintegration of Soviet Union in 1991 was neither the result of secessionist demands by its leadership nor any national liberation movement (Cuming, 2005).

Kazakhstan is situated at the centre of the Eurasian continent and occupies a territory of 2,717,300 square kilometers. In terms of area, Kazakhstan is the ninth largest country in the world and has a peculiar geostrategic situation; with almost all its territory coincides with Mckinder Heartland theory. Kazakhstan shares a border of $1700 \mathrm{~km}$ with China; both the countries share three rivers (Irytuysh, Emin and Ili) which further enhance the geopolitical importance of Kazakhstan vis-à-vis China (Abishev, 2002). Kazakhstan is located between two great powers - one Asian (China) and one Asian-European (Russia) - and to its south are the Central Asian countries of Uzbekistan, Turkmenistan and Kyrgyzstan. To enter this land-locked country, one should pass through the territory of these neighbouring countries.

During the time of the ancient Silk Road, both China and Kazakhstan were economically and culturally interlinked with each other through Xinjiang province. During the Soviet period, only informal trade existed between the two countries. But, after the independence of Kazakhstan, new land ports for facilitating trade were established on both sides of the border. The greatest momentum of economic ties between the two countries lies in the fact that the present Kazakhstan is rich in energy resources, which can fulfil the demands of energy-hungry China. In the era of globalization, where economic issues matter as much as security issues in deciding the strength of a nation in the world arena, Kazakhstan and China seek to enhance the complementary nature of their economies by forging strong economic linkages.

The importance of Kazakhstan is recognised by its vast oil and natural gas resources. In the initial phase after independence, various speculations were made about the amount of the oil and 
natural gas resources present in Kazakhstan. The energy resources present in Kazakhstan are vast, but the country is landlocked. To transport these energy resources to the refineries and the market, the erstwhile Soviet Union constructed the largest integrated pipeline network in the world. After the dissolution of the Soviet Union, new players, particularly China, has sought to secure access to these energy resources and transmission corridors.

Table 1.1 Estimated Energy Reserves

\begin{tabular}{|c|c|c|c|c|c|c|c|}
\hline & \multicolumn{7}{|c|}{ Estimated energy reserves } \\
\hline & \multicolumn{3}{|c|}{ Fossil Fuels } & \multirow{2}{*}{$\begin{array}{l}\text { Nuclear } \\
\text { Ura } \\
\text { Nium (1) }\end{array}$} & \multicolumn{2}{|c|}{ Renewables } & \multirow[b]{2}{*}{ Total } \\
\hline & Solid & Liquid & Gas & & $\begin{array}{l}\text { Hydro } \\
\text { (2) }\end{array}$ & $\begin{array}{l}\text { Solar } \\
\text { (3) }\end{array}$ & \\
\hline $\begin{array}{l}\text { Total } \\
\text { amount in } \\
\text { specific } \\
\text { units* }\end{array}$ & 170,200 & 6,500 & 1,820 & $1,500,000$ & 2,350 & $3,900,000$ & \\
\hline $\begin{array}{l}\text { Total } \\
\text { amount in } \\
\text { Exajoule } \\
\text { (EJ) }\end{array}$ & 942.20 & 31.16 & 66.28 & $\begin{array}{r}328.31 \\
(372.08\end{array}$ & 47.2 & 5.525 & 1420.7 \\
\hline
\end{tabular}

* Solid, Liquid: Million tons; Gas: Billion m³; Uranium: Metric tons; Hydro, Renewable: TW

(1) This total represents essentially recoverable reserves.

(2) For comparison purposes, a rough attempt is made to convert hydro capacity to energy by multiplying the gross theoretical annual capability (World Energy Council - 2002) by a factor of 10 .

Source: Statistical Yearbook.

Link:http://pub.iaea.org/MTCD/publications/PDF/CNPP2013_CD/countryprofiles/Kaza khstan/kazakhstan.htm

There are considerable hydrocarbon resources in Kazakhstan which is important for the world. As the second largest economic power in the world, China needs vast amounts of energy resources. However, the world market is under the control of dominant powers such as the United States control the international marine trade routes of oil transportation alongside important energy producing regions like the Middle East, North Africa, West Africa, Latin America and East Asia. In comparison, Kazakhstan's energy resources are available for China without the interference of an outside player. Kazakhstan could also supply energy by way of an intercontinental pipeline network from Central Asia and even through Iran. Also, Kazakhstan's energy resources are constant and 
useful for China's developing economy. The inauguration of oil transit pipeline from Kazakhstan to China in early 2005 is significant from this point of view. Besides the energy resources, China is also seeking raw materials, which are abundantly available in Kazakhstan. These show the eco-strategic importance of Kazakhstan. In this regard, the shaping and forming of Shanghai Cooperation Organization (SCO), which has two major energy producers (Russia and Kazakhstan) and major energy consumer (China) as its members.

\section{Kazakhstan and the New Great Game in Central Asia}

In the post-Soviet period, the three key players in the geopolitical space around Central Asia - Russia, China and the United States achieved a provisional equilibrium. Russia maintained its traditional dominance in its former southern Central Asian provinces. China, as it developed its economic relations with the Central Asian countries, gradually increased its own political influence, while seeking to avoid confrontation with Moscow. The United States, despite its preoccupation with other areas of greater strategic significance, kept a wary eye on the region. In the context of the "New Great Game", Kazakhstan has pursued a balanced foreign policy and worked to develop its economy, especially its hydrocarbon industry. While the country's economic outlook is improving, President Nazarbayev maintains strict control over the country's politics.

China has achieved a significant advantage over any potential competitors and created an important infrastructure base, which in a few years will probably be more modern and more powerful than that of Kazakhstan and Russia. It seems that even the intensification of Kazakhstan's foreign cooperation with Russia or the West will no more change this trend of increased interaction and convergence with China, as it will always be one step ahead of other interested parties. Another advantage in Beijing's favour is its ability to satisfy requests for the economic development of Kazakhstan. While Astana has faced foreign investors' reluctance to help its domestic manufacturing industry, China has proved more flexible and far-sighted, a situation that is well received by Kazakhstani leaders as a means to promote long-term plans. 


\section{China as a Major Player}

China's policy in Kazakhstan is associatedwithit's larger strategic and geopolitical interests. There is fear among the Chinese policymakerswith regard to the policy of 'opening up' of its northwestern frontier towards the Muslim Republics of Central Asia as it would invite the risk of Islamic fundamentalism and cross-border ethnic separatism which are grave threats to China's national security (Misra, 2001).

The collapse of USSR, the independence of Islamic Central Asian Republics, the continuing ferment among the Turkic Uygurs in Xinjiang province of China, and the emergence of a unipolar world dominated by the US, have been causes of concern for China. China looks for close and friendly ties with its Central Asian neighbours in general and Kazakhstan in particular.

Beijing is keen to play an important role in regional affairs making the best use of its political, economic and military capabilities. Independent Kazakhstan has provided China with an opportunity to re-assert its traditional regional interests. The Chinese policy has been to maintain peace and tranquillity along its border with Xinjiang. China has been wary of its minority ethnic group of Uygur Muslims being subjected to any separatist influence. So, Chinese position in Xinjiang depends as much on Beijing's ability to influence events across its border as it does on controlling events within.

The most important concern of China is the security of its border region in Xinjiang. Many Uighurs live in Kazakhstan and there is also a substantial Kazakh minority living in China's Xinjiang province both having their relatives living on either side of the border. This situation has caused serious disquiet in China, especially in the 1990s. However, after establishing good relations with neighbouring Central Asian countries and establishment of the SCO, China has ensured its security in Xinjiang besides promoting bilateral trade. Chinese policy towards Kazakhstan has thus been governed by both strategic and economic considerations, which have strong linkages with the geopolitics of Xinjiang. Kazakhstan has also attracted huge Chinese investment in oil and gas sectors and other industries. Shanghai-5 was a successful 
confidence-building effort. Eventually, this organisation, which was later renamed as SCO (Shanghai Cooperation Organisation) is serving as a vehicle for enhancing China's role in resolving regional security problems (Olcott, 2002).

China's policy in Kazakhstan has an economic angle which is largely based on its energy security needs and search for a market for its finished goods. Kazakhstan has proven oil reserves of about 2.6 billion tons and proven natural gas reserves of 3 trillion cubic meters. Kazakhstan's strength emanates from its rich energy and other natural resources and over the past few years, Kazakhstan has witnessed high economic growth due to the boom in oil prices (Konuralp, 2004).At the same time China, which is dependent on oil, imports it to sustain its high economic growth. For China, the economic development and cooperation of Central Asian Republics would help in promoting regional economic stability and prosperity, which in turn would lead to political stability and China needs a stable and peaceful international environment for its flourishing trade.

China's presence and influence in Central Asia, especially in Kazakhstan, have been increasing. The westward strategy articulated by Chinese President Xi Jinping in his "New Silk Road economic belt" highlights Central Asia's importance for Chinese economy and development. China has been investing billions of dollars in the energy sector which include a series of contracts with Kazakhstan worth $\$ 30$ billion, 31 agreements worth $\$ 15$ billion with Uzbekistan, and natural gas transactions with Turkmenistan in 2013, which reached about $\$ 16$ billion. Following tables and piecharts show, how China is emerging as a major player in Kazakhstan.

Table 1.2 Comparison of exports of Kazakhstan to China, Russia, and United States

\begin{tabular}{lll}
\hline \multicolumn{1}{c}{ Country } & 2000 (\% of total exports) & \multicolumn{1}{c}{2015 (\% of total exports) } \\
\hline China & 7.75 & 11.93 \\
United States & 2.04 & 0.95 \\
Russian Federation & 19.77 & 9.9 \\
\hline
\end{tabular}

Source: -http:// wits.worldbank.org/ Country Profile/en/ Country/ KAZ/Year/ 2000/TradeFlow/Export 
Table 1.3 Comparison of imports from China, United States and Russia

\begin{tabular}{|c|c|c|}
\hline Country & $\begin{array}{c}2000 \\
\text { (\% of total imports) }\end{array}$ & $\begin{array}{c}2015 \\
\text { (\% of total imports) }\end{array}$ \\
\hline China & 3.06 & 16.64 \\
\hline United States & 5.62 & 4.86 \\
\hline Russian Federation & 47.86 & 34.45 \\
\hline
\end{tabular}

Source:http:// wits.worldbank.org/CountryProfile/en/Country/KAZ/Year/LTST/TradeFl ow/Import/Partner/all/

Table 1.4 Percentage change in the imports and exports: Comparison of 2000 and 2015

\begin{tabular}{llr}
\hline \multicolumn{1}{c}{ Country } & Import & Export \\
\hline China & 543.79 increase & 53.9 increase \\
United States & 86.47 decrease & 53.4 decrease \\
Russian Federation & 71.9 decrease & 49.9 decrease \\
\hline
\end{tabular}

Table 1.5 Percentage change in imports and exports: 2016

\begin{tabular}{lrr}
\hline \multicolumn{1}{c}{ Country } & Trade (2016) & \multicolumn{1}{c}{ Trade in 2001 } \\
\hline China & $12.72 \%$ & $646,651+171,984=5.4 \%$ \\
United States & $3.05 \%$ & $347,205+142,412=3.2 \%$ \\
Russian Federation & $20.40 \%$ & $1,733,412+2,751,921=29.9 \%$ \\
\hline
\end{tabular}

\section{Trade of Khazakstan in 2016: Comparing China, United States and Russian Federation}

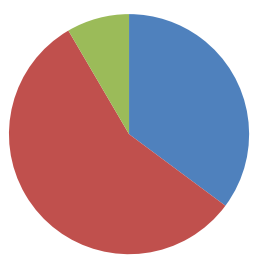

China (12.72)

Russia (20.04)

United States (3.05)

Fig 1.1 
Khazakstan total trade accounts in 2016: 36,775,323 (export) $+25,174,779$ (import) $=61950102$

Khazakstan total trade accounts in 2001:8,485,515 (export) $+6,280,202$ (import) $=14965717$

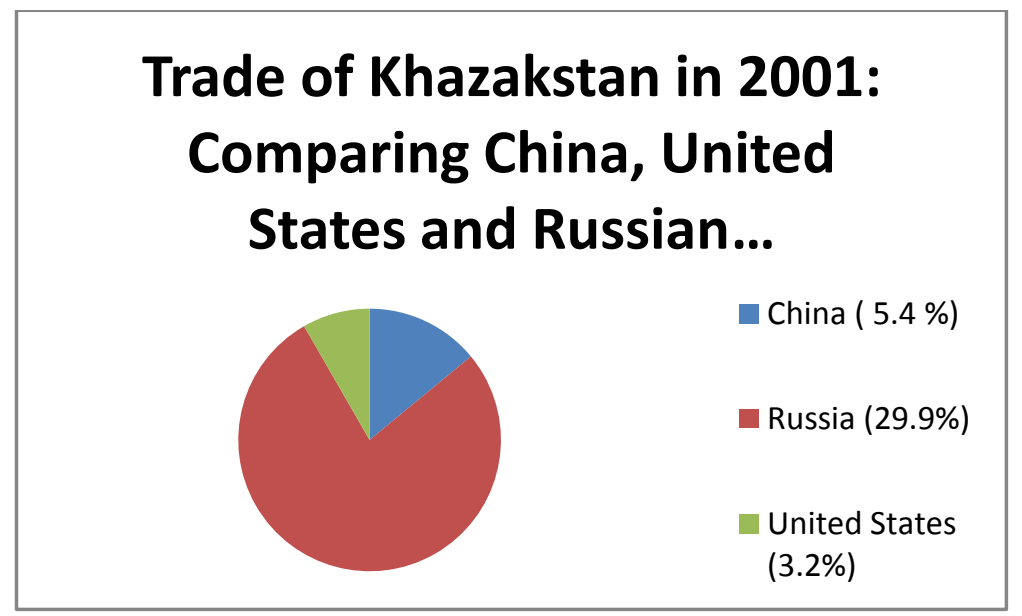

Fig 1.2

After comparing 16 years of data from 2000 to 2016, it is very much clear that china is in leading player compare to US and Russia. Over the last twenty years, the relationship between China and Kazakhstan has been carefully cultivated according to a comprehensive bilateral strategic partnership based on a contractual framework covering numerous agreements and documents. China is Kazakhstan's leading economic and trade partner and, Kazakhstan, among the post-Soviet states, is China's largest trading partner. The volume of mutual trade in 2016 reached $12.72 \%$ of total trade. In 2001, the percentage was a mere $5.4 \%$ of the total trade. In 2015, exports from Kazakhstan to China were $11.93 \%$ while it was $7.75 \%$ in 2000 .

At least 22 energy companies with Chinese participation are active in Kazakhstan's oil sector; ten of them are wholly or almost entirely controlled by Chinese investors. The share of Chinese companies in the Kazakh oil industry is expected to exceed $40 \%$ soon (Forbes, 2013). The most prominent participant is CNPC, which has acquired stakes in Kazakh energy companies and is involved in various upstream and infrastructure development projects. For 
example, it owns $60 \%$ of Kazakhstan's Aktobe Oil and Gas Corporation, a subsidiary of the national energy company Kaz Munai Gaz (KMG). Together with KMG, CNPC constructed the Kazakhstan-China oil pipeline, with a capacity of 12.5 million tonnes per year. The two companies are also constructing the Kazakhstan-China gas pipeline, which will eventually link up to the Central Asia-China pipeline network (Reuters, 2013).

China has rapidly become a major player in Kazakhstan. China's engagement in Kazakhstan stems from four basic factors. Firstly, Beijing wants to ensure its access to Kazakhstan's rich energy sources which is very important to meet its growing energy (particularly oil and gas) needs in the future. According to one estimate, China's domestic oil demand is expected to rise by around $4 \%$ annually (Singh, 2000). Kazakhstan has vast oil and natural gas reserves and at the end of 2008, Kazakhstan's proven total reserves of petroleum and natural gas were estimated to be $1500 \mathrm{~m}$. metric tons and threetrillion cubic meter respectively(The Europa World Year Book: 2008). Secondly, China wants to subdue the ethnoreligious nationalism in its Xinjiang province. Thirdly, it wants to protect its own political and economic interests in Kazakhstan vis-à-vis other external players. Finally, China wants access to the Kazakhstani market to sell its consumer goods.

Chinese interest in Central Asia did not emerge simultaneously but arose sequentially. The priorities of China's diplomacy have been changing ever since the disintegration of the USSR and the formation of independent states in Central Asia in 1991, China has been continuously rethinking its interests and policy in the region (Rumer, Eugene, Dmitri \& Zhao, 2007, pp.170-172).

Border dispute was another issue. When the USSR dissolved, SinoSoviet border talks were half completed. In 1989 China and the Soviet Union initiated the Sino-Soviet agreement on the Eastern section of the border. However, the two parties had not yet reached agreement on the western section of the border. There is only a 45 kms border between China and Russia in the western section. Far more extensive are the borders between China and the newly independent Central Asian countries. These are more than 1700 kms with Kazakhstan, about 1000 kms with Kyrgyzstan, and about $450 \mathrm{kms}$ with Tajikistan. The four ex-Soviet Republics (Russia, 
Kazakhstan, Kyrgyzstan and Tajikistan) decided to hold further negotiations with China. In September 1994, the parties reached an agreement on the western section of the Sino-Russian border, where, after Sino-Soviet armed border clashes in 1969, both sides had deployed troops and equipment on a huge scale. With the improvement in bilateral relations, the countries significantly reduced military forces deployed in the border regions but still required an institutional mechanism to guarantee border security. To meet this need on 26th April 1996 China, Russia, Kazakhstan, Kyrgyzstan and Tajikistan signed the treaty of deepening military trust in border regions, which contained the following provisions.

1. Military forces deployed in border regions will not attack each other.

2. No side will conduct military exercises that are targeted at each other.

3. The scale, range and number of military activities scheduled to be conducted within $100 \mathrm{~km}$ of the border

4. Each side will invite the other to observe military exercises that involve the use of live ammunition.

5. Dangerous military activity are to be avoided and

6. Friendly communications between military forces and frontier guards in border regions should be promoted.

On the basis of this treaty, in 1997 the parties agreed to reduce the military forces in the border regions;

1. Military forces deployed in border regions were to be reduced to a level compatible with good neighbourly relations and defensive in nature.

2. No side would use, or threaten to use, force against the other or unilaterally seek military superiority

3. The military forces deployed in border regions would not attack the other side.

4. All sides would reduce the number of military personnel including the army, air force, air defence forces, and frontier guards, and also reduce the quantity of the main categories of weaponry deployed with 100 kilometres of the border.

5. The upper limit after reduction, as well as the method and time limit for implementation, would be specified at a later date. 
6. The parties would exchange pertinent information on military forces in border regions and

7. Implementation of treaty was to be supervised.

These two agreements (the treaty on deepening military trust in border regions and the treaty on reduction of military forces in border regions) are of fundamental significance for the border security of China, Russia, and the Central Asian States. Border security and stability have always been the central focus of China's diplomacy in Central Asia. Resolution of border issues and border security are a prerequisite for China's goal of a favourable environment.

However, border security has been moved down in China's list of priorities since 1997.The 1998 Almaty joint statement of the "Shanghai five" proclaimed, for the first time that the member states (Russia, China, Kyrgyzstan, Kazakhstan and Uzbekistan) would unite to combat terrorism and that none would allow its own territory to be used for activities that harm the sovereignty, security, and social order of another member state. These countries established the SCO on 15 June 2001 and adopted the Shanghai "convention on combating terrorism, separatism and extremism". This meant not only a redefinition of SCO activities but also a reconsideration of China's interests in Central Asia. The main motive for this change was the resolution of border issues and creation of an institutional guarantee of border security. Resolution of border and security issues also resulted in a qualitative change in the relations between China and the Central Asian countries and made more extensive cooperation possible (Ibid., pp. 170-172).

The primary goal of China's anti-terrorist policy in Central Asia is to counteract the "East Turkestan" movement in Xinjiang - that is, maintain stability in northwestern China and oppose a separatist division of the country. The northwest region has always been a problem for China's central governments.

\section{Kazakhstan's Interests in China}

On its part, Kazakhstan also needs Chinese assistance in attaining several of its objectives: Firstly, it needs Chinese economic assistance and policy guidance for its domestic economic growth. Secondly, Kazakhstan views China as a strong alternative to Russia 
to lessen its dependence on the latter. China has been able to help Kazakhstan to exploit and export the energy resources available in Kazakhstan by providing ample investment funds and exporting routes. Thirdly, Kazakhstan also wants to avert any possible ethnic extremism from its complex ethnographic structure, which has some commonality with that of Xinjiang province of China. Finally, Kazakhstan finds in China a lucrative market for its exports.

Since the establishment of their diplomatic links, both sides have been exchanging high-level visits with each other. Serious attempts are being taken by both the nations to resolve mutual difficulties and elevate the political and economic relations between them. A "Historic Border Accord" was signed between the two nations on 26 April 1994 on the eve of the then Chinese Prime Minister Li Peng's visit to Kazakhstan (Zardykhan, 2002). On this occasion the two countries agreed to eliminate all transport restrictions between them and affirmed the inviolability of their current borders (Hunter, 1996, pp.124-125).

It is important to note here that the Xinjiang province of China plays a major role in Kazakh-China trade and economic relations. It is the only province of China which shares a common border with Kazakhstan. In fact, a major part of Kazakhstan's trade with China is concentrated in the Xinjiang province. For example, Xinjiang's share in Kazakh-China trade in 1996 was more than 90\% (Raczka, 1998).

Importantly, of the five Central Asian countries, Kazakhstan remained the largest trading partner with China. Its annual growth rate was \$434 million (Liu, 1998). But in 1994, China's trade with Central Asian states was $\$ 577$ million, which was 5\% less than in 1993. In particular, China's trade with Kazakhstan came substantially down to $\$ 335$ million, $22 \%$ less than the amount in 1993. This was due to trade adjustments in export and import policy between Kazakhstan and China, besides the export of some shoddy consumer goods made in China and exported to Kazakhstan in 1993 which seriously damaged the reputation of Chinese exports. 
Table 1.6 Sino-Kazakhstan Trade, 1992-2010 (in million dollars)

\begin{tabular}{cc}
\hline Year & Trade Volume \\
\hline 1992 & 363 \\
1993 & 435 \\
1994 & 363 \\
1995 & 390 \\
1997 & 528 \\
2002 & 313 \\
2004 & 758.1 \\
2006 & 1924.9 \\
2007 & 2240 \\
2008 & 1432 \\
2009 & 1377 \\
2010 & 996.1 \\
\hline
\end{tabular}

Source: IMF, “The People's Republic of China” 1998, Trade Statistics Yearbook August 1998, p.158 (United Nations Commodity Trade Statistics database).

Though there was a slow growth over the years in the volume of trade between Central Asian states and China, there is enough scope for the increase of trade between them. In 1997, China's total trade with Kazakhstan was \$ 528 million and in 2010, it was \$ 996.1 million.

\section{Kazakhstan's Place in Chinese Diplomacy}

Kazakhstan is important to China and constitutes one of the key dimensions of its foreign policy. Chinese diplomacy divides relations with the outside world into three basic categories: great powers, neighbouring countries, and developing countries. Relations with great powers mainly seek to resolve issues pertaining to the international structure and strategic balance. Links with surrounding countries concentrate mainly on issues pertinent to China's immediate environment. Relations with developing countries primarily concern the issues of China's posture toward the south-north contradictions and its relations with a vast number of small and medium-sized countries. Maintaining international recognition of one China and creating international conditions to resolve the Xinjiang, Tibet and Taiwan issues are strategic goals of China's diplomacy.

In the realm of Chinese diplomacy, Kazakhstan is considered as a medium-sized partner and hence does not belong to the category of 
major powers. Kazakhstan's ranking corresponds to the Chinese conception of "periphery diplomacy", one of the principal concepts in its foreign strategy. This concept has three connotations: First, it refers to the neighbouring countries that share borders with China. Second, it not only refers to contiguous states but also those that are very close, such as Japan and South Korea. Third, as China's diplomacy developed, it has extended the concept of periphery still further. This notion refers to peripheral areas that are important for China's security, economic, and political interests. The concept of a larger periphery has some ambiguity in practice; it can be expanded without limit and include the Middle East and even farther territories. The concept of the larger periphery is employed mainly at the theoretical level and rarely used in diplomatic practice. There is no corresponding larger periphery policy (Rumer et al. 2007, pp. 170-172). The goal of China's peripheral strategy is to promote friendly relations with all the contiguous or proximate countries that form a stable belt around the country.

The collapse of the Soviet Union reduced the principal security threat to China. An optimistic assessment of China's role in a multipolar world has caused greater concern in Beijing about the emergence of US-led unipolarity. Beijing used this as an opportunity to play a new role in regional affairs that would make the best use of its political, economic and military capabilities. The emergence of independent Kazakhstan gave China the opportunity to reassert its traditional regional interests.

From China's perspective, the disintegration of the Soviet Union accelerated the process of de-linking local and regional conflicts from superpower rivalry. Beijing sees opportunities among the competing interests of contiguous (Iran, Pakistan, India and Russia) and non-contiguous (Turkey and Saudi Arabia) actors in Central Asia. China's ability to play a new geopolitical game in Kazakhstan is based on "comprehensive national strength" that encompasses political, cultural, social, and economic as well as traditional interests. Geography also favours its active role in Kazakhstan (Walsh, 1993).

China has the capacity to link with Kazakhstan through trade as well as politics. The geopolitical situation near western China is 
delicate, as the Xinjiang province shares a border with half a dozen countries including Afghanistan, Pakistan, India and most of the members of the Shanghai Cooperation Organization. Many of these countries have both internal and external security problems. Since China's problems in Xinjiang are ethnoreligious and separatist, clearly China is wary of the disturbances involving people of the same religion or ethnic origin of the Uyghur minority.

\section{Conclusion}

For the first time in its history, China is actually leading an international coalition. This leadership can be seen in China's role as an initiator of the coalition Shanghai Cooperation Organization. Although the Shanghai Cooperation Organization is only a regional organisation, nobody can deny its importance when it comes to playing its role in Central Asia. At the same time, China's active role in the region has its consequences. If China becomes too active in its new role, it might cause suspicion among other states and would thus be accused of pushing for hegemony. Since the exSoviet states in the region are sensitive to threats to their sovereignty, a development of this kind could lead to the collapse of the Shanghai Cooperation Organization, which would jeopardise not only China's prospects in the region but also the peaceful development in Central Asia.

Many external powers wanted to fill the vacuum created by the disintegration of the former USSR. The Islamic states tried to influence the region through their belief in a universal Islam and wanted to bring the region into their fold. Powerful external powers are also attracted towards the region in order to keep it under their influence because of the geostrategic, geopolitical and geo-economic significance of the region. The regimes in Central Asia are also faced with a dilemma as to which side they should tilt. The external powers came to the region with a basket of offers in order to help the regimes in Central Asia come out of their problems. However, the Central Asian states have been cautious in doing business with external powers keeping in mind the Russian factor. 
Neither Kazakhstan nor China is in favour of rising western influence in their adjacent regions. While China's policy always supports multipolar world order, Kazakhstan does not wish to be entrapped in the sphere of American hegemony. Thisis reflected in the increasing cooperation between China and Kazakhstan.

Importantly, China appreciates the importance of Kazakhstan in several dimensions and accordingly devises its policy with care. When dealing with Kazakhstan, China also keeps in mind other important factors, such as Russia, the United States, and Islamic fundamentalism. As a result, Kazakhstan is approached from the broader perspective of Central Asia and the states beyond. At the same time, however, China does differentiate between Kazakhstan and Central Asia, giving Sino-Kazakh relations special attention in its strategic thinking and undertakings. While China deals with all the Central Asian states on the basis of equality, it places special emphasis on Kazakhstan. This corresponds both to Kazakhstan's importance in the region and it coincides with the national interests of both countries.

\section{References}

Gordeyeva, M. (2013). China buys into giant Kazakh oilfield for $\$ 5$ billion. Reuters, September, 7. Retrieved from: http://www.reuters.com/ article/2013/09/07/us-oil-kashagan-china-idUSBRE986066 20130907? FeedType=RSS \& eedName=topNews\& utm_source $=$ dlvr.it \& utm_medium=twitter\&dlvrit=992637.

Abbishev, A. E. (2002). Kazakhstan in Focus: Ten Years of Independence. Almaty: Center for Foreign Policy and Analysis.

Cuming, S.N. (2005). Kazakhstan Power and the Elite. New York: St. Martin Press Inc.

Hunter, S. T. (1996). Central Asia since Independence (pp.124-125). Washington D.C: Praeger.

Ibid., pp. 170-172.

Konuralp, E. (2004). China in Central Asia: A Case Study of Relationship between China and Kazakhstan. Contemporary Central Asia, 8(3).

Liu, Q. (1998). Sino-Central Asian Trade and Economic Relations: Progress, Problems and Prospects. In Ethnic Challenges beyond Borders (pp. 179-200). Palgrave Macmillan UK. 
Misra, S. S. (2001). Chinese Perspectives on Central Asia: Threat of Uighur Separatism. Journal of Peace Studies, 8(3).

Olcott, M. B. (2002). Kazakhstan: Unfulfilled Promise, Carnegie Endowment for International Peace. Washington D.C: Brooking Institution Press.

Raczka, W. (1998). Xinjiang and its Central Asian Borderlands. Central Asian Survey, 17(3)

Rumer, E., Dmitri, T. and Huasheng, Z. (2007). Central Asia: Views from Washington, Moscow and Beijing (pp. 170-172). London: M.E. Sharpe.

Singh, S. (2000, November 1). Sino-Central Asian Engagement: Limitation vs. Leverage, Special Lecture, Centre for Central Eurasian Studies.

Maher, J. (2008). The Europa World Year Book 2008 (Vol. 1). Routledge.

Forbes. (2013, January 12). Как Храпуновы бизнес вели. Retrieved from http://forbes.kz/process/probing/v_rk_rabotayut_22_neftyanyie_ko mpanii_s_kitayskim_uchastiem

Walsh, J. R. (1993). China and the New Geopolitics of Central Asia. Asian Survey, 33(3).

Zardykhan, Z. (2002).Kazakhstan and Central Asia: Regional Perspectives. Central Asian Survey, 21(2). 